\title{
FIXATION OF POTASSIUM BY SOIL SAMPLES UNDER VARIOUS CONDITIONS
}

\author{
Armi Kaila \\ University of Helsinki, Department of Agricultural Chemistry
}

Received February 26, 1965

In a previous paper (2) results were reported on the fixation of potassium by Finnish mineral soils. The capacity of the samples to retain potassium against an extraction with neutral ammonium acetate ranged from 0 to 72 per cent of the 2.5 me $\mathrm{K}$ added per $100 \mathrm{~g}$ soil, being on the average about 15 per cent in the samples of surface layer and about 30 per cent in the samples of subsoil. Although the fixation was positively correlated with the clay content of the soil, also samples of a coarser texture, even some finesand soils, fixed a marked part of the potassium applied.

The fixation of added potassium was determined by a procedure in which the soil sample was in contact with the KCl-solution only one hour before the extraction with ammonium acetate. It was emphasized that the results would be distinctly higher, if the period of contact would be longer, or if the suspension were dried. In the present paper the fixation is studied under various conditions, including incubation for three months or drying at a higher temperature. The dependence of the fixation on the amount of potassium added, and on the lime and potassium status of the soil is also studied.

\section{Material and methods}

The soil samples of the present work are listed in Table 1. The sample Vi 2 is from virgin land, the samples To 1 and Sa 1 were taken from clay pits; all the other samples originate from cultivated land, the sample Vi 1 from the edge of a ditch.

According to the mechanical analysis there are 19 clay soils, containing more than 30 per cent of the fraction $<2 \mu, 8$ silt soils, 2 loam soils and one finesand soil 
Table 1. Soil sampes

\begin{tabular}{|c|c|c|c|c|c|c|c|c|c|c|}
\hline & & & \multirow{2}{*}{$\begin{array}{c}\text { Depth } \\
\text { cm }\end{array}$} & \multirow{2}{*}{$\mathrm{pH}$} & \multirow{2}{*}{$\begin{array}{c}\text { Org. C } \\
\%\end{array}$} & \multicolumn{5}{|c|}{ Particle size fractions, $\%$} \\
\hline & & & & & & $0.6 \mu$ & $0.6-2 \mu$ & $2-6 \mu$ & $6-20$ & $-200 \mu$ \\
\hline \multirow[t]{3}{*}{ Vi } & $1 \mathrm{a}$ & Silty clay & $0-20$ & 3.5 & 2.9 & 34 & 12 & 14 & 21 & 18 \\
\hline & b & Clay loam & $20-40$ & 3.6 & 2.9 & 32 & 10 & 13 & 22 & 21 \\
\hline & c & Silty clay & $40-65$ & 3.3 & 2.2 & 40 & 11 & 12 & 22 & 14 \\
\hline \multirow[t]{3}{*}{ Vi } & 2 a & Sandy clay & $0-20$ & 4.8 & 1.0 & 33 & 12 & 9 & 9 & 25 \\
\hline & b & Heavy clay & $20-40$ & 5.2 & 0.5 & 57 & 17 & 8 & 4 & 11 \\
\hline & c & , & $40-65$ & 5.8 & 0.4 & 72 & 17 & 8 & 1 & 2 \\
\hline \multirow[t]{3}{*}{ Vi } & 3 a & Silty clay & $0-20$ & 4.4 & 4.6 & 37 & 10 & 14 & 17 & 17 \\
\hline & b & Clay loam & $20-40$ & 3.7 & 2.1 & 44 & 10 & 12 & 12 & 21 \\
\hline & c & Heavy clay & $50-70$ & 3.6 & 1.6 & 54 & 18 & 12 & 9 & 6 \\
\hline \multirow[t]{3}{*}{ Le } & 1 a & Clay loam & $0-20$ & 5.3 & 5.5 & 18 & 14 & 19 & 10 & 34 \\
\hline & b & Heavy clay & $45-60$ & 5.7 & 0.6 & 46 & 24 & 10 & 7 & 12 \\
\hline & c & Silty clay & $95-105$ & 6.3 & 0.3 & 16 & 24 & 32 & 22 & 5 \\
\hline \multirow[t]{3}{*}{ HP } & $1 \mathrm{a}$ & Silt & $0-20$ & 6.1 & 2.5 & 4 & 14 & 27 & 41 & 11 \\
\hline & b & , & $30-40$ & 5.8 & 1.1 & 4 & 14 & 24 & 56 & 1 \\
\hline & c & , & $50-60$ & 6.0 & 0.1 & 2 & 12 & 24 & 42 & 19 \\
\hline \multirow[t]{3}{*}{$\mathrm{HP}$} & $2 \mathrm{a}$ & Silt & $0-20$ & 5.8 & 2.2 & 3 & 13 & 30 & 38 & 15 \\
\hline & b & , & $30-40$ & 6.0 & 0.5 & 1 & 7 & 28 & 46 & 17 \\
\hline & c & , & $50-60$ & 6.2 & 0.6 & 4 & 13 & 19 & 59 & 5 \\
\hline \multirow[t]{3}{*}{ HP } & 3 a & Clay loam & $0-20$ & 5.1 & 2.3 & 6 & 24 & 22 & 17 & 29 \\
\hline & & Loam & $30-40$ & 4.9 & 1.3 & 10 & 18 & 25 & 23 & 22 \\
\hline & c & Silty clay & $50-60$ & 5.0 & 0.2 & 2 & 34 & 49 & 9 & 4 \\
\hline \multirow[t]{3}{*}{$\mathrm{HP}$} & $4 \mathrm{a}$ & Silty clay & $0-20$ & 4.9 & 3.0 & 11 & 19 & 39 & 17 & 13 \\
\hline & b & 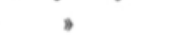 & $45-60$ & 5.9 & 0.2 & 12 & 24 & 36 & 17 & 11 \\
\hline & c & , & $95-105$ & 6.0 & 0.3 & 9 & 29 & 44 & 12 & 6 \\
\hline \multirow[t]{3}{*}{ To } & 1 a & Silt & $5-15$ & 4.7 & 1.4 & 2 & 9 & 22 & 39 & 27 \\
\hline & b & Silty clay & $20-30$ & 6.2 & 0.5 & 12 & 28 & 35 & 22 & 3 \\
\hline & c & Silt & $40-50$ & 6.4 & 0.4 & 2 & 16 & 32 & 40 & 10 \\
\hline \multirow[t]{3}{*}{$\mathrm{Sa}$} & $1 \mathrm{a}$ & Loam & $10-20$ & 5.2 & 0.6 & 17 & 7 & 9 & 27 & 35 \\
\hline & & Finesand & $30-40$ & 5.8 & 0.2 & 14 & 4 & 6 & 24 & 51 \\
\hline & c & Heavy clay & $90-100$ & 6.3 & 0.2 & 70 & 13 & 7 & 4 & 6 \\
\hline
\end{tabular}

sample. The soil $\mathrm{pH}$, determined in 1:2.5 suspension in $0.01 \mathrm{M} \mathrm{CaCl}_{2}$, is very low in the samples Vi 1 and Vi 3 which are typical Litorina soils, marine sediments rich in organic matter and sesquioxides. In most of the other soils at least the deeper layers are only slightly acid. 
The total potassium of the soil was determined by the $\mathrm{Na}_{2} \mathrm{CO}_{3}$ fusion. The acid soluble potassium was estimated by treating a 5-g sample for 20 hours with $50 \mathrm{ml}$ of $\mathrm{N} \mathrm{HCl}$ at $50^{\circ} \mathrm{C}$, and the exchangeable potassium by an extraction with $1 \mathrm{~N}$ ammonium acetate in the ratio of 1 to 10 for 1 hour. All the potassium determinations were performed by an EEL-flame photometer.

The fixation of potassium was determined either by the "wet" method used by Schactschabel and Köster (9) in which $10 \mathrm{~g}$ of soil is shaken in $25 \mathrm{ml}$ of 0.01 $\mathrm{N} \mathrm{KCl}$ for one hour, $25 \mathrm{ml}$ of neutral $1 \mathrm{~N}$ ammonium acetate is added, and the suspension shaken for an other hour, or by the "dry" method of the same writers in which the $\mathrm{KCl}$-suspension is dried at $80^{\circ} \mathrm{C}$ before an extraction with $50 \mathrm{ml}$ of $0.5 \mathrm{~N}$ ammonium acetate. In addition, a similar "wet" procedure was used in which the period of contact in the $\mathrm{KCl}$-suspension was 18 hours. The fixation of potassium from various applications was determined by the rapid wwet" method using $0.0025 \mathrm{~N}$ to $0.16 \mathrm{~N} \mathrm{KCl}$-solutions.

\section{Results}

The total potassium content of the samples is relatively high (Table 2), in the surface layers from 1.99 to 2.81 per cent $\mathrm{K}$, and in the deeper layers from 2.41 per cent in the finesand soil Sa $1 \mathrm{~b}$ to 3.41 per cent in the heavy clay sample Vi $2 \mathrm{c}$. In the different layers of the same soil, the acid soluble potassium tends to vary with the content of total potassium, being in most cases lowest in the surface layer. The amount of this mainly moderately availablen form of soil potassium appears to be low in the samples of a coarser texture, except in the soil To 1 which is known to be rich in micaceous minerals. The highest value, $22.1 \mathrm{me} \mathrm{K} / 100 \mathrm{~g}$ in the sample Vi $2 \mathrm{c}$, is five times as high as the content of acid-soluble potassium in the surface samples HP $1 \mathrm{a}, 2 \mathrm{a}$, and $3 \mathrm{a}$. The data for the mexchangeable" potassium are likely to be too low, since the samples were not washed with fresh extractant after the filtration. In the cultivated soils, the plough layer seems to be somewhat richer in this form of potassium than the deeper layers, probably owing to the application of fertilizers. No correlation exists between the contents of "exchangeable" potassium and the acidsoluble potassium.

In most cases, extending the period of contact between the soil sample and the $\mathrm{KCl}$-solution from one hour to 18 hours has markedly increased the amount of potassium fixed (Table 2). Drying of the suspension has given values which are, on the average, about twice as high as those by the "wet" method of 18 hours. In some soils the former results are even almost four times as high as those of the latter one, while in samples which are capable to fix large amounts of potassium under the wet conditions, this ratio is, of course, low.

In this material the finesand soil sample Sa $1 \mathrm{~b}$ has the highest capacity to fix potassium applied at the rate of $2.5 \mathrm{me} / 100 \mathrm{~g}$. Within one hour under the "wet" conditions this soil has fixed 84 per cent of the added potassium, within 18 hours 90 per cent, and drying has increased this part to 98 per cent. Only the silty clay soil Le $1 \mathrm{c}$ has under wet conditions been capable of fixation of an equal order. When the treatment included drying, more than one third of the samples fixed at least 80 per cent 
Table 2. $\mathrm{K}$ in the soil samples and fixation of $\mathrm{K}$ applied at the rate of $2.5 \mathrm{me} / 100 \mathrm{~g}$

\begin{tabular}{|c|c|c|c|c|c|c|c|}
\hline & & \multirow{3}{*}{$\begin{array}{c}\text { Tot. K } \\
\%\end{array}$} & \multirow{2}{*}{$\begin{array}{l}\text { Acid- } \\
\text { soluble }\end{array}$} & \multirow{2}{*}{$\begin{array}{c}\text { Exchange- } \\
\text { able }\end{array}$} & \multicolumn{3}{|c|}{$\mathrm{K}$ fixed me $/ 100 \mathrm{~g}$} \\
\hline & & & & & \multirow{2}{*}{$\begin{array}{l}\text { wets } \\
1 \text { hour }\end{array}$} & \multirow{2}{*}{$\begin{array}{l}\text { swets } \\
18 \text { hours }\end{array}$} & \multirow[t]{2}{*}{ dry } \\
\hline & & & $\mathrm{K}$ me & $/ 100 \mathrm{~g}$ & & & \\
\hline \multirow[t]{3}{*}{$\mathrm{Vi}$} & $1 \mathrm{a}$ & 2.62 & 14.0 & 0.49 & 0.41 & 0.56 & 1.14 \\
\hline & b & 2.54 & 11.8 & 0.39 & 0.37 & 0.47 & 0.89 \\
\hline & c & 2.68 & 15.0 & 0.45 & 0.50 & 0.56 & 1.38 \\
\hline \multirow[t]{3}{*}{$\mathrm{Vi}$} & 2 a & 2.81 & 11.3 & 0.52 & 0.45 & 0.47 & 1.40 \\
\hline & b & 3.27 & 18.0 & 0.65 & 0.72 & 0.84 & 2.12 \\
\hline & c & 3.41 & 22.1 & 0.81 & 0.87 & 1.08 & 2.00 \\
\hline \multirow[t]{3}{*}{$\mathrm{Vi}_{\mathrm{i}}$} & 3 a & 2.27 & 9.3 & 1.11 & 0.38 & 0.45 & 0.75 \\
\hline & b & 2.68 & 11.4 & 0.61 & 0.33 & 0.41 & 0.64 \\
\hline & c & 3.06 & 14.2 & 0.64 & 0.47 & 0.59 & 0.77 \\
\hline \multirow[t]{3}{*}{ Le } & 1 a & 2.12 & 7.5 & 0.47 & 0.39 & 0.50 & 1.46 \\
\hline & b & 3.08 & 14.2 & 0.44 & 1.17 & 1.63 & 2.26 \\
\hline & c & 3.13 & 16.1 & 0.20 & 1.92 & 2.29 & 2.45 \\
\hline \multirow[t]{3}{*}{ HP } & $1 \mathrm{a}$ & 2.61 & 4.4 & 0.12 & 0.57 & 0.72 & 1.83 \\
\hline & b & 2.78 & 5.0 & 0.12 & 0.59 & 0.73 & 1.95 \\
\hline & c & 2.78 & 5.8 & 0.10 & 0.70 & 0.96 & 2.02 \\
\hline \multirow[t]{3}{*}{ HP } & 2 a & 2.56 & 4.2 & 0.26 & 0.32 & 0.32 & 1.07 \\
\hline & b & 2.77 & 4.9 & 0.09 & 0.65 & 0.85 & 1.89 \\
\hline & c & 2.80 & 6.8 & 0.13 & 0.97 & 1.24 & 2.19 \\
\hline \multirow[t]{3}{*}{$\mathrm{HP}$} & 3 a & 2.54 & 4.3 & 0.48 & 0.34 & 0.26 & 0.96 \\
\hline & b & 2.68 & 4.7 & 0.24 & 0.25 & 0.25 & 0.55 \\
\hline & c & 3.08 & 9.3 & 0.22 & 0.48 & 0.53 & 1.94 \\
\hline \multirow[t]{3}{*}{$\mathrm{HP}$} & 4 a & 2.68 & 5.8 & 0.22 & 0.48 & 0.52 & 1.90 \\
\hline & b & 2.98 & 8.8 & 0.20 & 1.05 & 1.27 & 2.18 \\
\hline & c & 3.14 & 12.6 & 0.25 & 0.75 & 0.83 & 1.93 \\
\hline \multirow[t]{3}{*}{ To } & $1 \mathrm{a}$ & 1.99 & 8.0 & 0.15 & 0.23 & 0.32 & 1.21 \\
\hline & b & 2.86 & 19.7 & 0.34 & 0.60 & 0.95 & 2.00 \\
\hline & c & 2.60 & 16.7 & 0.14 & 0.81 & 1.15 & 2.36 \\
\hline \multirow[t]{3}{*}{$\mathrm{Sa}$} & $1 \mathrm{a}$ & 2.51 & 5.9 & 0.18 & 0.85 & 1.14 & 2.03 \\
\hline & b & 2.41 & 5.5 & 0.17 & 2.10 & 2.25 & 2.45 \\
\hline & c & 3.17 & 9.0 & 0.68 & 1.58 & 1.81 & 2.28 \\
\hline
\end{tabular}

of the added potassium; among these samples are also the silt soils HP $1 \mathrm{c}$ and $2 \mathrm{c}$ and To $1 \mathrm{c}$, and the loam soil Sa $1 \mathrm{a}$. On the other hand, there are samples, as the loam soil HP 3 b and the clay loam soil Vi 3 b, which even then fixed only 22 and 26 per cent of the added potassium, respectively. 
The fact that drying the KCl-suspension has exerted different effects on the potassium fixation of the different soil samples also appears in the relatively low correlation between the results of the "dry" fixation and those of the "wet" methods. The total linear correlation coefficients between these variables are only $0.73^{* * *}$ and $0.78^{* * *}$, the former value indicating the relation between the "dry" fixation and the "wet" fixation during one hour, the latter during 18 hours.

In the previous study (2) the fixation of potassium under "wet" conditions during one hour was positively correlated with the contents of finer and coarser clay, and $\mathrm{pH}$ of the soil, and negatively correlated with the content of organic matter, although the connection was not particularly close in any case. In the present small material the "dry" fixation does not seem to have any connection with the clay content, but it is positively correlated with $\mathrm{pH}\left(\mathrm{r}=0.75^{* * *}\right)$ and negatively correlated with the organic carbon $\left(\mathrm{r}=-0.63^{* * *}\right)$. The content of acid soluble potassium is not related with the "dry" fixation, but a low negative correlation appears to exist between the latter and the content of exchangeable potassium $\left(\mathrm{r}=-0.40^{*}\right)$. In the larger material studied (2) there was no correlation between the "wet" fixation and the content of exchangeable potassium.

The amount of potassium applied in all these determinations was 2.5 me $\mathrm{K} / 100 \mathrm{~g}$ soil. The fixation of potassium under the "wet" conditions was also studied, when the applications were one half or one fourth of this amount, or twice, four times, eight times, or sixteen times as high as it. The period of contact was one hour. These results are reported in Table 3 as the percentage of the application.

The pattern of the fixation in the various soils differs to an appreciable degree. Generally, of course, a larger part is fixed from the lower applications than from the higher ones. Yet, there are several sampels which have fixed an only slightly lower portion of the application of $40 \mathrm{me} \mathrm{K} / 100 \mathrm{~g}$ than of the application of $0.625 \mathrm{me}$ $\mathrm{K} / 100 \mathrm{~g}$. In these cases the fixation has been mainly less than 20 per cent of the amount added. On the other hand, there are samples which have fixed almost completely the lowest applications, but only a moderate part of the higher ones. The most striking example is the finesand soil Sa $1 \mathrm{~b}$ with a fixation of about 90 per cent of the applications of 0.625 and $1.25 \mathrm{me} \mathrm{K} / 100 \mathrm{~g}$, and 18 per cent of the highest addition. The silty clay sample Le $1 \mathrm{c}$ shows a similar tendency, though less distinctly. Thus the fixation ranges from 10 to 91 per cent of the 0.625 me K/100 g added, but only from 10 to 32 per cent of the application of $40 \mathrm{me} \mathrm{K} / 100 \mathrm{~g}$.

The highest amounts of potassium fixed by these soils during the one hour's contact with a $\mathrm{KCl}$-solution range from 4 to almost $13 \mathrm{me} \mathrm{K} / 100 \mathrm{~g}$. It is obvious that these quantities do not represent the maximum fixation capacity under these conditions, although the maximum will be relatively near for samples such as the finesand soil Sa 1 b.

There is also a feature which may be noteworthy. The highest fixation percentage is not always to be found in connection with the lowest potassium addition. For example the samples Vi 2 b, Vi 2 c, Le 1 b and Sa 1 c have fixed the highest relative amount of added potassium from the application of $5 \mathrm{me} \mathrm{K} / 100 \mathrm{~g}$. In more than one third of the samples a somewhat lower part has been fixed of 0.625 me K/100 g than of $1.25 \mathrm{me} \mathrm{K} / 100 \mathrm{~g}$. These small differences may, however, be due to the short 
Table 3. Percentage of the applied $\mathrm{K}$ fixed under wet conditions

\begin{tabular}{|c|c|c|c|c|c|c|c|c|c|}
\hline & & & \multicolumn{7}{|c|}{$\mathrm{K}$ applied $\mathrm{me} / 100 \mathrm{~g}$} \\
\hline & & & 0.625 & 1.25 & 2.5 & 5.0 & 10.0 & 20.0 & 40.0 \\
\hline \multirow[t]{3}{*}{$\mathrm{Vi}$} & 1 & a & 22 & 22 & 20 & 17 & 17 & 14 & 14 \\
\hline & & b & 18 & 20 & 17 & 15 & 15 & 14 & 13 \\
\hline & & c & 24 & 24 & 22 & 17 & 17 & 16 & 13 \\
\hline \multirow[t]{3}{*}{$\mathrm{Vi}$} & 2 & a & 16 & 14 & 18 & 16 & 16 & 15 & 17 \\
\hline & & b & 25 & 26 & 29 & 31 & 27 & 20 & 20 \\
\hline & & c & 34 & 35 & 35 & 36 & 32 & 26 & 23 \\
\hline \multirow[t]{3}{*}{$\mathrm{Vi}$} & 3 & a & 16 & 16 & 15 & 20 & 19 & 15 & 15 \\
\hline & & $\mathrm{b}$ & 19 & 18 & 17 & 16 & 15 & 15 & 15 \\
\hline & & c & 22 & 18 & 19 & 18 & 19 & 17 & 17 \\
\hline \multirow[t]{3}{*}{ Le } & 1 & a & 22 & 16 & 16 & 18 & 19 & 14 & 16 \\
\hline & & b & 38 & 44 & 47 & 51 & 44 & 31 & 24 \\
\hline & & c & 74 & 84 & 77 & 71 & 54 & 37 & 25 \\
\hline \multirow[t]{3}{*}{$\mathrm{HP}$} & 1 & a & 26 & 22 & 22 & 20 & 17 & 15 & 13 \\
\hline & & b & 26 & 26 & 24 & 19 & 16 & 13 & 13 \\
\hline & & c & 32 & 29 & 28 & 20 & 16 & 13 & 13 \\
\hline \multirow[t]{3}{*}{$\mathrm{HP}$} & 2 & a & 14 & 10 & 13 & 13 & 15 & 13 & 11 \\
\hline & & $\mathrm{b}$ & 27 & 34 & 26 & 22 & 18 & 12 & 12 \\
\hline & & $\mathrm{c}$ & 45 & 50 & 39 & 31 & 24 & 18 & 15 \\
\hline \multirow[t]{3}{*}{ HP } & 3 & $\mathrm{a}$ & 19 & 11 & 17 & 14 & 15 & 14 & 14 \\
\hline & & b & 13 & 9 & 13 & 11 & 13 & 12 & 12 \\
\hline & & c & 18 & 17 & 19 & 17 & 17 & 15 & 13 \\
\hline \multirow[t]{3}{*}{ HP } & 4 & a & 19 & 19 & 19 & 19 & 17 & 16 & 13 \\
\hline & & b & 35 & 46 & 42 & 32 & 24 & 19 & 12 \\
\hline & & c & 24 & 30 & 30 & 24 & 20 & 15 & 12 \\
\hline \multirow[t]{3}{*}{ To } & 1 & a & 10 & 10 & 9 & 9 & 11 & 11 & 10 \\
\hline & & $\mathrm{b}$ & 21 & 27 & 24 & 19 & 17 & 14 & 12 \\
\hline & & c & 26 & 34 & 31 & 25 & 20 & 14 & 12 \\
\hline \multirow[t]{3}{*}{$\mathrm{Sa}$} & 1 & a & 27 & 36 & 34 & 31 & 26 & 19 & 17 \\
\hline & & $\mathrm{b}$ & 91 & 90 & 84 & 67 & 43 & 28 & 18 \\
\hline & & $\mathrm{c}$ & 50 & 56 & 63 & 63 & 53 & 39 & 32 \\
\hline
\end{tabular}

period of contact and to the not so thorough extraction by the ammonium acetate for the removing of the part of potassium which was not fixed.

It is of interest to note that the fixation of potassium from the application of $40 \mathrm{me} \mathrm{K} / 100 \mathrm{~g}$ is correlated with the content of the clay fraction $<0.6 \mu\left(\mathrm{r}=0.70^{* * *}\right)$ whereas the fixation from the lowest application, $0.625 \mathrm{me} \mathrm{K} / 100 \mathrm{~g}$, is not $(\mathrm{r}=0.08)$. 
This seems to be connected with the fact that samples, such as the silt soil HP $2 \mathrm{c}$ and the finesand soil Sa $1 \mathrm{~b}$, contain coarser material which effectively fixes potassium, but there is not enough of this material to provide a total fixation capacity as high as that in the soils with a finer texture.

The dependence of the fixation of potassium on the lime and potassium status of the soil was studied using soil samples incubated in the laboratory with applications of lime and potassium. First a series of acid loam, clay loam and silty clay samples were analysed, when they had been incubated at room temperature for six months with $0,5,10$, or $20 \mathrm{~g} \mathrm{CaCO}_{3}$ per kilogram of soil. The results of the determination of the fixation of potassium under "wet» conditions during one hour are reported in Table 4. The fixation has been relatively low in all samples, and although the

Table 4. Fixation of $\mathrm{K}$ under wet conditions by samples at various lime status

(Expressed as a percentage of the 2.5 me $\mathrm{K}$ added per $100 \mathrm{~g}$ of soil)

\begin{tabular}{|c|c|c|c|c|c|c|c|c|}
\hline & \multicolumn{2}{|c|}{$\mathrm{No}_{\mathrm{CaCO}}$} & \multicolumn{2}{|c|}{$\mathrm{CaCO}_{3} 5 \mathrm{~g} / \mathrm{kg}$} & \multicolumn{2}{|c|}{$\mathrm{CaCO}_{3} 10 \mathrm{~g} / \mathrm{kg}$} & \multicolumn{2}{|c|}{$\mathrm{CaCO}_{3} 20 \mathrm{~g} / \mathrm{kg}$} \\
\hline & $\mathrm{pH}$ & $\mathrm{K}$ fixed & $\mathrm{pH}$ & K fixed & $\mathrm{pH}$ & K fixed & $\mathrm{pH}$ & $\mathrm{K}$ fixed \\
\hline Vi 1 a Silty clay & 3.5 & 20 & 4.2 & 21 & 5.1 & 22 & 6.5 & 24 \\
\hline Vi 1 c & 3.3 & 18 & 3.9 & 21 & 4.8 & 22 & 6.7 & 26 \\
\hline Vi 4 a Loam & 4.2 & 16 & 5.4 & 17 & 6.4 & 16 & 6.8 & 17 \\
\hline Vi 4 c Clay loam & 4.1 & 16 & 6.3 & 22 & 6.9 & 22 & 7.0 & 22 \\
\hline Vi 6 a Loam & 4.1 & 12 & 5.5 & 14 & 6.4 & 15 & 6.9 & 15 \\
\hline Vi 6 c Silty clay & 4.1 & 18 & 5.3 & 19 & 6.0 & 21 & 6.9 & 22 \\
\hline
\end{tabular}

liming has been able to increase the fixation more than 20 per cent in most soils, the results, even at the highest level of lime are moderate despite of the markedly reduced acidity. Thus, it is not only the acidity which in these acid soils limits the fixation of potassium.

In an other incubation experiment the silt soil samples HP 1 and HP 2, and the loam, clay loam and silty clay samples HP 3 were kept at room temperature for three months after they were treated with water or $\mathrm{KCl}$-solutions at the rates corresponding to 0.5 me or $2.5 \mathrm{me} \mathrm{K} / 100 \mathrm{~g}$ soil. It appears (Table 5) that the application of potassium has increased the content of exchangeable potassium in the samples, but that particularly in the samples HP 1, HP 2 b and c, and HP $3 \mathrm{c}$ at least three fourth of the added potassium is no more extractable with $1 \mathrm{~N}$ neutral ammonium acetate. The amounts of potassium fixed when 2.5 me $\mathrm{K} / 100 \mathrm{~g}$ was added under wet conditions are, in general, the lower, the higher the potassium treatment before the incubation was. In the silt soil HP $1 \mathrm{c}$, the amount fixed by the sample incubated with the higher addition of potassium is less than one fourth of that fixed by the sample incubated without the potassium treatment. On the other hand, the clay loam soil HP 3 a seems to fix potassium almost at the same rate at the various potassium levels.

Also under the field conditions the application of potassium fertilizers may to some extent reduce the fixation of potassium by the soils. In a longterm field experi- 
Table 5. Fixation of $\mathrm{K}$ under wet conditions by soil samples at various $\mathrm{K}$ status

\begin{tabular}{|c|c|c|c|c|c|c|c|}
\hline & & \multicolumn{3}{|c|}{ Exhangeable $\mathrm{K}$ me/100 g } & \multicolumn{3}{|c|}{$\mathrm{K}$ fixed $\mathrm{me} / 100 \mathrm{~g}$} \\
\hline & & 0 & 0.5 me $\mathrm{K}$ & $2.5 \mathrm{me} \mathrm{K}$ & 0 & 0.5 me K & 2.5 me K \\
\hline \multirow{3}{*}{ HP } & $1 \mathrm{a}$ & 0.12 & 0.21 & 0.65 & 0.52 & 0.41 & 0.29 \\
\hline & b & 0.12 & 0.21 & 0.62 & 0.59 & 0.32 & 0.24 \\
\hline & c & 0.09 & 0.15 & 0.53 & 0.72 & 0.34 & 0.17 \\
\hline \multirow[t]{3}{*}{ HP } & 2 a & 0.21 & 0.69 & 1.66 & 0.33 & 0.27 & 0.24 \\
\hline & b & 0.09 & 0.16 & 0.71 & 0.66 & 0.27 & 0.24 \\
\hline & c & 0.12 & 0.17 & 0.36 & 1.04 & 0.47 & 0.30 \\
\hline \multirow[t]{3}{*}{ HP } & 3 a & 0.38 & 0.99 & 1.97 & 0.32 & 0.30 & 0.29 \\
\hline & b & 0.26 & 1.13 & 2.40 & 0.28 & 0.28 & 0.18 \\
\hline & c & 0.21 & 0.33 & 0.71 & 0.39 & 0.25 & 0.23 \\
\hline
\end{tabular}

ment on silty clay soil, the samples of the plots treated with potassium fixed, on the average, $0.32 \mathrm{me} \mathrm{K} / 100 \mathrm{~g}$, and those from the untreated plots $0.40 \mathrm{me} \mathrm{K} / 100 \mathrm{~g}$. In an other experiment the corresponding values were 0.41 and $0.52 \mathrm{me} \mathrm{K} / 100 \mathrm{~g}$. In both cases the fixation was determined by the rapid "wet" method using the application of $2.5 \mathrm{me} \mathrm{K} / 100 \mathrm{~g}$.

The combined effect of lime and potassium on the fixation of potassium was also studied. The incubation experiment, examined above, included in addition to the treatments with potassium, a treatment with $\mathrm{CaCO}_{3}$ corresponding to $5 \mathrm{~g} / \mathrm{kg}$ soil, and a treatment with both this amount of $\mathrm{CaCO}_{3}$ and $2.5 \mathrm{me} \mathrm{K} / 100 \mathrm{~g}$ soil. The samples incubated for three months were analysed for the fixation of potassium of an application of $2.5 \mathrm{me} / 100 \mathrm{~g}$ under wet conditions. The results are recorded in Table 6 .

The $\mathrm{pH}$-values measured in $0.01 \mathrm{M} \mathrm{CaCl}_{2}$-suspension, indicate that liming has effectively reduced the acidity. Only the most acid samples HP 3 a and HP 3 b were not brought up to neutrality. The reduction of the acidity has exerted different effect on the various samples. The fixation of potassium is in the limed samples HP 1 a 56 per cent and HP 1 b 47 per cent higher than in the unlimed ones. In the samples HP 2 a and HP 3 a, the corresponding figures are only 9 per cent and 6 per cent, respectively. The limed sample HP $3 \mathrm{c}$ has fixed more than twice as much as the unlimed one. These differences between the various soils may, to a certain extent, be connected with the differences in the $\mathrm{pH}$ and the buffering capacity of the soils, but other explanations are also needed.

The effect of liming on the potassium fixation appears to be almost negligible when it is connected with the treament with potassium applied at this high rate. Only in the samples HP $1 \mathrm{c}$ and HP $3 \mathrm{c}$ the fixed amounts are somewhat higher in the limed samples than in the unlimed ones.

On the basis of the content of exchangeable potassium in the samples of this incubation experiment an estimation of the fixation of applied potassium during the 
Table 6. Fixation of $\mathrm{K}$ under wet conditions by soil samples at various lime and $\mathrm{K}$ status

\begin{tabular}{|c|c|c|c|c|c|c|c|c|c|}
\hline & & \multicolumn{4}{|c|}{$\mathrm{pH}$} & \multicolumn{4}{|c|}{$\mathrm{K}$ fixed $\mathrm{me} / 100 \mathrm{~g}$} \\
\hline & & 0 & $\mathrm{CaCO}_{3}$ & K & $\mathrm{K}+\mathrm{CaCO}_{3}$ & 0 & $\mathrm{CaCO}_{3}$ & K & $\mathrm{K}+\mathrm{CaCO}_{3}$ \\
\hline & & & & & & & & & \\
\hline \multirow[t]{3}{*}{$\mathrm{HP}$} & $1 \mathrm{a}$ & 5.4 & 7.0 & 5.3 & 6.8 & 0.52 & 0.81 & 0.29 & 0.28 \\
\hline & b & 5.1 & 7.1 & 5.1 & 7.1 & 0.59 & 0.87 & 0.24 & 0.26 \\
\hline & c & 5.7 & 7.3 & 5.5 & 7.3 & 0.72 & 0.89 & 0.17 & 0.21 \\
\hline \multirow[t]{3}{*}{ HP } & 2 a & 5.3 & 6.7 & 5.3 & 6.8 & 0.33 & 0.36 & 0.24 & 0.25 \\
\hline & b & 5.8 & 7.3 & 5.6 & 7.3 & 0.66 & 0.84 & 0.24 & 0.26 \\
\hline & c & 6.1 & 7.4 & 5.9 & 7.4 & 1.04 & 1.22 & 0.30 & 0.32 \\
\hline \multirow[t]{3}{*}{$\mathrm{HP}$} & $3 \mathrm{a}$ & 4.6 & 6.1 & 4.6 & 6.0 & 0.32 & 0.34 & 0.29 & 0.24 \\
\hline & b & 4.6 & 6.5 & 4.4 & 6.4 & 0.28 & 0.34 & 0.18 & 0.18 \\
\hline & c & 4.9 & 7.0 & 4.6 & 7.1 & 0.39 & 0.81 & 0.23 & 0.34 \\
\hline
\end{tabular}

incubation may be obtained. It is supposed that the changes in the soil potassium due to the incubation are similar both in the samples treated with potassium and in the corresponding untreated ones. In this way results reported in Table 7 are calculated. It also contains the data obtained when unincubated samples were analysed for the fixation of potassium by the "wet" and "dry" laboratory procedures using the same addition of potassium as in the incubation experiment, $2.5 \mathrm{me} \mathrm{K} / 100 \mathrm{~g}$ soil.

The part of potassium fixed during the incubation appears to be of the same order as that fixed by the dry method. Incubation with lime has only slightly increased the amount fixed. While in all the other samples the data for the "dry" fixation are equal or somewhat lower than those for the fixation during incubation,

Table 7. Fixation of $\mathrm{K}$ under various conditions

\begin{tabular}{|c|c|c|c|c|c|}
\hline & & \multicolumn{4}{|c|}{ Per cent of applied $\mathrm{K}$ fixed } \\
\hline & & \multicolumn{2}{|c|}{ unincubated } & \multicolumn{2}{|c|}{ incubated } \\
\hline & & swets & edry" & without lime & with lime \\
\hline \multirow[t]{3}{*}{ HP 1} & $1 \mathrm{a}$ & 29 & 73 & 78 & 82 \\
\hline & b & 29 & 78 & 80 & 84 \\
\hline & c & 38 & 81 & 82 & 84 \\
\hline \multirow[t]{3}{*}{ HP : } & 2 a & 13 & 43 & 44 & 45 \\
\hline & b & 34 & 76 & 76 & 78 \\
\hline & c & 39 & 88 & 96 & 97 \\
\hline \multirow[t]{3}{*}{ HP : } & 3 a & 10 & 38 & 36 & 37 \\
\hline & b & 10 & 22 & 14 & 16 \\
\hline & c & 21 & 78 & 79 & 81 \\
\hline
\end{tabular}


the order in the sample HP $3 \mathrm{~b}$, perhaps also in the sample HP $3 \mathrm{a}$, is the contrary. When these samples were incubated with the lower application of potassium, $0.5 \mathrm{me}$ $\mathrm{K} / 100 \mathrm{~g}$, no fixation could be detected. Thus either the rather marked increase in the acidity in these samples during the incubation, or some other changes have reduced their capacity to fix potassium as compared with the unincubated samples.

\section{Discussion}

The results of the present study, for their part, demonstrate that the data for the fixation of potassium by soil largely depends on the procedure used for the determination. The amount of potassium fixed under the "wet" conditions from an application of $2.5 \mathrm{me} \mathrm{K} / 100 \mathrm{~g}$ during one hour was, on the average, somewhat more than 80 per cent of that fixed during 18 hours, ranging from about 60 to more than 100 per cent. The amount of potassium fixed when the $\mathrm{KCl}$-suspension was dried at $80^{\circ} \mathrm{C}$ was 1.2 to 4.1 times as high as that fixed without drying during one hour. The correlation coefficient for the linear relation between these variables was only $\mathrm{r}=0.73^{* * *}$. This may be partly attributed to the fact that some samples fixed under the "wet" conditions about 80 per cent of the potassium applied, and the application was for these samples too low to allow maximum fixation under the "dry" conditions. On the other hand, the relatively poor correlation is likely to arise from the differences in the mineral composition of the soils.

The fixation determined by the "dry" method was found to be of the same order as that occurring during the incubation for three months at room temperature and subsequent air-drying. Further studies are needed to show to what extent the results of the "dry" method would correspond to the fixation under the field conditions. The markedly lower results of the "wet" methods may, however, be more valuable from the plant nutritional point of view, since the potassium fixed under the "wet" conditions is claimed to be more difficultly available to the plants than the potassium fixed under the "dry" conditions (9).

Even the fixation of potassium under the "wet" conditions was high by the samples studied. When 40 me $\mathrm{K} / 100 \mathrm{~g}$ was applied, the samples fixed from 4 to 13 $\mathrm{me} / 100 \mathrm{~g}$ soil, and this was obviously in most cases far from the maximum capacity. There seemed to be different patterns of fixation. In general, the portion fixed decreased with the increase in the application, but some soils fixed an almost equal portion of all applications from 0.625 to $40 \mathrm{me} \mathrm{K} / 100 \mathrm{~g}$. Also the fact may be noteworthy that in several soils the highest fixation percentage was found not of the lowest application but of the second, third or fourth application. Similar results occur also elsewhere (12).

Although the fixation of potassium under the "wet" conditions is supposed to be mainly due to the vermiculites and expanding illites (8) and connected with the clay fraction, also soils of a coarser texture are known to be capable to fix considerable amounts of potassium $(2,7)$. In the present paper a finesand soil containing 18 per cent of the fraction $<2 \mu$, fixed up to the application $2.5 \mathrm{me} \mathrm{K} / 100 \mathrm{~g}$ more potassium than any of the other samples, or from 91 to 84 per cent of the amount added. The portion fixed by this soil decreased then rapidly with an increase in the application, 
and it was only 18 per cent of the addition of $40 \mathrm{me} \mathrm{K} / 100 \mathrm{~g}$. Yet, this corresponds to a fixation of more than 7 me K/100 g soil. Expressed as the amount fixed per $100 \mathrm{~g}$ of clay, it would be $40 \mathrm{me} \mathrm{K}$. In the silt soils studied the corresponding value ranges from 26 to $61 \mathrm{me} \mathrm{K} / 100 \mathrm{~g}$ of clay. These figures are so high that it seems to be more reliable to attribute a marked part of the fixation to fractions $>2 \mu$, particularly, since it is known that there may be considerable fixation by the coarser fractions $(1,6)$. According to Barshad (1) a large part of the ammonium and potassium fixation resides in the coarser fraction of the soils associated with vermiculite-like minerals, and Soveri (10) has detected vermiculites in all the Finnish samples studied, even in the silt fraction.

The present observations on the the effect of the lime and potassium status of the soil on the fixation of potassium are in accordance with results of other studies $(3,4,5,11,12)$.

\section{S $u m m$ ary}

The fixation of added potassium under various conditions was studied using soil samples collected from three layers of ten mineral soils. The type of soil ranged from finesand to heavy clay, the soil reaction from $\mathrm{pH} 3.3$ to $\mathrm{pH} 6.4$ (in $0.01 \mathrm{M} \mathrm{CaCl}_{2}$ ), and the total potassium content from 1.99 to 3.41 per cent.

The fixation against an extraction with neutral ammonium acetate distinctly depended on the conditions used for the application of potassium: on the average, without drying the samples fixed during one hour somewhat more than 80 per cent of the amount fixed during 18 hours, when the samples were treated with $\mathrm{KCl}$ solutions corresponding to $2.5 \mathrm{me} \mathrm{K} / 100 \mathrm{~g}$ soil. Drying the suspension at $80^{\circ} \mathrm{C}$ resulted in a fixation 1.2 to 4.1 times as high as that under the "wet" conditions within one hour. The results of these two methods were not particularly closely correlated $\left(\mathrm{r}=0.73^{* * *}\right)$. The results of the "dry" method were found to be of the same order as the fixation of potassium in samples incubated for three months at room temperature.

The results of the "dry" fixation were positively correlated with the $\mathrm{pH}(\mathrm{r}=$ $\left.0.75^{* * *}\right)$ and negatively correlated with the contents of organic carbon $(\mathrm{r}=$ $\left.-0.63^{* * *}\right)$ and exchangeable potassium $\left(\mathrm{r}=-0.40^{*}\right)$, but they were not correlated with the contents of clay or the acid soluble potassium.

Under the "wet" conditions the relative fixation generally decreased with an increase in the application of potassium, but there were samples which fixed a rather low but almost equal portion of all the applications from 0.625 to 40 me $\mathrm{K} / 100 \mathrm{~g}$ soil. The fixation from the highest addition was correlated with the clay fraction $<0.6 \mu$, but not with the coarser clay, whereas the fixation from the lowest application was not correlated with the clay content.

Particular attention was paid to the intensive fixation of potassium by a finesand soil (84 to 91 per cent of the applications of 2.5 to $0.615 \mathrm{me} \mathrm{K} / 100 \mathrm{~g}$ soil under wet conditions), and some silt soils. When $40 \mathrm{me} \mathrm{K} / 100 \mathrm{~g}$ was added these samples fixed amounts corresponding to 26 to $61 \mathrm{me} \mathrm{K} / 100 \mathrm{~g}$ of clay, which may be taken to indicate that in these soils also the coarser fractions may be associated with the fixation. 
The fixation of potassium under the "wet" conditions by samples adjusted to various lime and potassium status in incubation experiments or in field trials was studied. Usually liming increased the fixation, although the effect was not always marked. Application of potassium salts tended to decrease the fixation capacity. When potassium had been applied at a high rate, the effect of liming on the fixing appeared to be almost negligible.

\title{
REFERENCES
}

(1) Barshad, I. 1951. Cation exchange in soils I. Soil Sci. 72: $361-371$.

(2) Kalla, A. 1965. Fixation of potassium in Finnish soils. J. Sci. Agr. Soc. Finland 37: 116-126.

(3) Karlsson, N. 1952. Kalium i marken. Kgl. Lantbr. Akad. Tidskr: 91: 297-329.

(4) KerĀnen, T. 1946. Kaliumista Suomen maalajeissa. Summary: On potassium in Finnish soils. Acta Agr. Fennica 63, 114 p.

(5) Maclean, A. J. 1962. Fixation of potassium in some Canadian soils. Canad. J. soil Sci. 42: $96-104$.

(6) $\rightarrow-\&$ BRYDON, J. E. 1963. Release and fixation of potassium in different size fractions of some Canadian soils as related to their mineralogy. Ibid. 43: 123-134.

(7) Nӧммıк, H. 1961. Kalium- und Ammoniumfixierung in schwedischen Ackerböden. Kgl. Lantbr. Akad. Tidskr. Suppl. 5: 28-39.

(8) Sснаснтsснaвel, P. 1961. Fixierung und Nachlieferung von Kalium- und Ammonium-Ionen. Landw. Forsch. Sonderh. 15: 29-47.

(9) - - \& Köster, W. Chemische Untersuchungen an Marschen II. Zeitschr. Pflanzenern. Düng. Bodenk. 89: 148-159.

(10) Soveri, U. 1956. The mineralogical composition of argillaceous sediments of Finland. Ann. Acad. Scient. A III 48.

(11) Stanford, G. 1947. Fixation of potassium in soils under moist conditions and on drying in relation to type of clay mineral. Soil Sci. Soc. Amer. Proc. 12: 167-170.

(12) Wiklander, L. 1960. Kalium i skånska âkerjordar. Socker. Handl. I 16: 51-63.

\section{S ELOSTUS :}

KALIUMIN PIDÄTTYMISESTÅ MAAHAN VAIKEASTI VAIHTUVAAN MUOTOON ERI OLO-

\section{SUHTEISSA}

\author{
ARMi KaILA
}

Yliopiston maanviljelyskemian laitos, Pihlajamäki

Tulokset, jotka saadaan tutkittaessa maan kykyä pidättää kaliumia vaikeasti vaihtuvaan muotoon riippuvat olennaisesti käytetystä menetelmästä. Erityisesti vaikuttavat lisätyn kaliumin määrä, kontaktin pituus ja varsinkin suspension kuivattaminen ennen vaihtuvaksi jäăneen kaliumin uuttamista.

Tutkittujen 30 kivennäismaanäytteen kaliumin pidätyksen maksimia ei saavutettu, vaikka lisätyn kaliumin määrä oli jopa $40 \mathrm{me} \mathrm{K} / 100 \mathrm{~g}$ maata, jolloin näytteet pidättivät vaikeasti vaihtuvaan muotoon 4-13 me K/100 g. Eri maanäytteillä näytti olevan erilainen pidätyksen tyyppi. Erityisen mielenkiintoinen oli hietamaa, joka pystyi pienimmistä kaliumin lisäyksistä $(0.625,1.25$ ja 2.5 me K/100 g) pidättämään kuivattamatta $91-84 \%$, mutta jonka suhteellinen pidätyskyky aleni suurempia määriä käytettäessä nopeammin kuin useitten savimaitten. Tässä samoin kuin tutkituissa hiesumaissa oli ilmeisesti savifraktiota karkeampien ainesten osuus pidätyksessä merkittävä.

Kalkituksella voitiin yleensä lisätä ja kalilannoituksella vähentää maan kykyä pidättää lisättyä kaliumia vaikeasti vaihtuvaksi. 